\title{
Assessment of Bamboo Species Under Eastern U.P. Conditions
}

\author{
Ashok Kumar* and Abhinav Kumar \\ Department of Floriculture \& Landscaping, College of Horticulture \& Forestry \\ N. D. University of Agriculture \& Technology, Faizabad-224 229 (U. P.), India \\ *Corresponding author
}

\section{A B S T R A C T}

\begin{tabular}{|l|}
\hline Ke y w or d s \\
Bamboo, Shoots, \\
Clump, Girth \\
\hline Article Info \\
\hline $\begin{array}{l}\text { Accepted: } \\
\text { 26 October } 2018 \\
\text { Available Online: } \\
\text { 10 November } 2018\end{array}$ \\
\hline
\end{tabular}

\section{Introduction}

Bamboo a fast growing perennial versatile woody grass is widely distributed across the country. It belongs to the grass family Poaceae (Gramineae). In India nearly, 125 indigenous as well as exotic species of bamboo belonging to 23 genera are distributed in tropical and subtropical regions. The richest reserves of bamboo forest $(14 \%)$ are distributed in North East region. Among the available species, 19 species have been identified for their high economic values. The most valuable species belong to genera Bambusa, Dendrocalamus, Malocanna, Ochlandra, Oxytenanthera and Phyllostachy, which are having variable height $(10-40 \mathrm{~m})$, diameter $(5-25 \mathrm{~cm})$, colour, number of culms (150 - 1500), wood maturity
$(5-20$ years $)$ and prolonged seeding cycle $(30$ -60 years).

Bamboo plantation has immense potential for improving the socio-economic status of rural and tribal areas, employment generation, protection of environment and degraded forest, effective mechanism of erosion control for watershed, flood prone areas and river banks, ravine land, mud slides etc. It is an excellent material for housing and construction, furniture and handicrafts, cottage industries, paper and rayon industries, plywood, packaging, transportation etc. Uttar Pradesh is one of the leading States in India, which occupied largest geographical area of 2.41 thousand sq $\mathrm{km}(7.33 \%)$ and more than 20 percent population of India. Out of these 
population, more than three fourth of the population resides in about 97,000 villages. Out of the 15 Agro-climatic Zones of India, U.P. covers nine zones. Out of the total land resources, 167.50 lakh ha is covered under cultivated area, 17.80 lakh ha in forest areas and 135 lakh ha area is occupied in different categories of wastelands i.e. revine land (12.30 lakh ha), salt affected (12.195 lakh ha), diara land (15.0 lakh ha) and water logged (8.10 lakh ha). The per capita availability of land is very low (0.15 lakh ha). The maximum agricultural land holding is small $(73.8 \%)$ and marginal holding is less than 1 ha. About $73 \%$ workers are engaged in agricultural and allied activities and $7.7 \%$ engaged in small scale /cottage industries. The poverty and unemployment is the two main barriers to socio-economic upliftment in rural areas.

As per land use pattern and agro-climatic conditions of eastern Uttar Pradesh, it has vast potential of land and water resources covering 26 districts. However, maximum area also comes under flood prone, drought /rained areas, problematic land (12.26 lakh ha) and denuded forest (3.66 lakh per ha), which are distributed in to three distinct zones viz. Eastern Gangetic plain, Eastern Tarai Zone and Vindhayan Zone. These zones are most potential to grow number of variable species of bamboo under different land resources viz. water logged /watershed area, ravine, diara lands, salt affected land, wasteland, drought prone areas /moisture stress, denuded forest land and agricultural cultivable lands as biofencing, wind breaks, check of soil erosion. In Eastern parts of Uttar Pradesh, a number of genetic bio-diversity of bamboo is distributed in rural and forest areas. The maximum biodiversity of Dendrocalamus stlictus is widely occurring in forest areas of Vindhayan and Bundlekhand region-covering Sonbhadra, Chaundali, Mirzapur, Chitrakoot, Jhansi, Lalitpur, Banda districts. In addition to this, other species viz. Bambusa arundinaceae, $B$. tundra, B. nutans, B. chloris, D. hemittonii are also distributed in different pockets of eastern districts i.e. Basti, Gonda, Faizabad, Sultanpur, Jaunpur, Varanasi, Ghazipur, Gorakhpur, Deoria, Ballia, Mirzapur, Pratapgarh and Azamgarh. These variable species / genotypes are traditionally grown surrounding the ponds, tanks, watershed areas, eroded lands, farm boundary, road side, riverside, reservoir, canal and wastelands. However, the productivity of these local grown species varies from 250 - 1500 culms per clump, which regenerate and grow more than 8-60 years and fetches high return to the farmers. The plantation of bamboo on agricultural lands, wasteland, watershed and eroded lands will boost up the rural economy, job opportunity to rural poor, landless laborers, utilization and conservation of watershed /waterlogged and eroded /degraded and denuded forest lands. However, presently bamboo plantation has become boon to protection of flood prone areas, utilization of problematic lands and cheapest building materials in earthquake prone /landslide areas. Due to a forestation and over-exploitation, most of the locally grown bamboo species, are reaching to extinction and causing misbalances to rural economy and agro-ecoenvironments as well as discouragement to the cottage and handicrafts industries in rural areas. In facts, there is no any species on earth, which has vast potential and values to quality of life in rural and urban areas. It is also grown very easily with minimum inputs, plant care and free from pests and diseases. Thus, bamboo plantation has immense scope and economic potential for sustainable development of rural areas in eastern parts of Uttar Pradesh.

As per statistical reports of Govt. of India, at present total world market of bamboo is valued to US\$10 Billion, which is expected to increase to tune of US\$20 Billion. The values of domestic bamboo industry are estimated to 
about Rs. 6505 crores, which may exceed to Rs. 26,000 crores. Keeping in view the importance of bamboo a project was initiated with the objective of "Establishment of clonal garden of important bamboo species for multiplication and distribution of improved planting stock".

\section{Materials and Methods}

An ad hock project sponsored by National Bamboo Mission, Ministry of Agriculture, Department of Agriculture \& Cooperation; Govt. of India was carried out to establish a clonal garden at Department of Floriculture and Landscape, College of Horticulture and Forestry, Narendra Deva University of Agriculture and Technology, Faizabad (U.P.), India during 2009-10 to 2011-12. Nine bamboo species were collected from G.B Pant University of Agriculture \& Technology, Pantnagar, Udham Singh Nagar, Uttarakhand, during July 2009 and 2010. Collected off sets of various species along with their accession number are given here and further details of each clones and their passport data for each clone is available at G.B Pant University of Agriculture \& technology, Pantnagar, Udham Singh Nagar, Uttarakhand.

\section{The clones (species) collected (with Accession Number)}

Collected off-sets were shifted in the nursery of Main Experimental Station (MES), Department of Horticulture, College of Horticulture \& Forestry, N. D. University of Agriculture \& Technology, Kumarganj, Faizabad, having fertile loam soil ( $\mathrm{pH} 7.8$ and carbon content $3.8 \%$ ). Field was prepared by 3 ploughing followed by planking and cleanining weeds and old crop stubles. Off sets were transplanted at the distance of 4.00 $\mathrm{x} 4.00$ meter each in well prepred pits. Pits of size $0.45 \times 0.45 \times 0.45$ meter were dug and were filled with fertile top soil $+5.00 \mathrm{~kg}$ well rotten FYM + 25 g methyl parathion to avoid soil insect. After transplatings of offsets light irrigation was done. Multiplied species were utilized in eastablishement of clonal garden at Main Experimental Station (MES), Department of Horticulture and also provided to needy farmers interested in bamboo cultivation for area expension. Each collected clones were transplanted in line in the sequence. From each Species 3 plants were randomly selected and treated as replication and each clone were treated as treatments. For the analysis of data for number of shoots developed per clump and for girth three thickest shoots were selected in each clump and measured girth at fifth internodes through vernier calipers and mean was calculate. Meteorological data were recorded for various aspects like maximum and minimum temperature, relative humidity (\%), sun shine hours (hours) and total rainfall ( $\mathrm{mm})$. The analysis was done by the procedure as suggested by Gomez and Gomez (1984) for randomized block design.

\section{Results and Discussion}

Data were recorded for the number of shoots developed per clump and girth at $5^{\text {th }}$ internodes $(\mathrm{cm})$ for each clone showed significant performance as indicated in the table 1-3. The maximum number of sprouts per clump were recorded in Bambusa balcooa (16.00) followed by Bambusa nutans (15.00) and Dendracalamus strictus (14.00), however minimum number of sprouts per clumps were recorded in Bambusa bambos and Dendracalmus hamiltonii (6.00) each and Dendrocalmus asper and Thyrsostaehyus oliberi could not sprout at the end of first year of plantation. The maximum girth were noticed in Dendracalmus hamiltonii $(5.09 \mathrm{~cm})$ followed by Bambusa bambos $(4.08 \mathrm{~cm})$ and Bambusa vulgaris $(3.37 \mathrm{~cm})$ and minimum girth were noted in Bambusa balcooa (1.60 $\mathrm{cm})$ and Bambusa nutans $(1.88 \mathrm{~cm})$ after one year of planting. 
Table.1a The clones (species) collected (with Accession Number)

\begin{tabular}{|c|c|c|c|c|c|}
\hline \multirow[t]{2}{*}{ Sl. No. } & \multirow[t]{2}{*}{ Clone (Species) } & \multicolumn{3}{|c|}{ Accession Number (From GBPUA\&T) } & \multirow{2}{*}{$\begin{array}{l}\text { Number of of } \\
\text { set collected }\end{array}$} \\
\hline & & Line No. & $\begin{array}{l}\text { Propagule } \\
\text { type }\end{array}$ & Collection source & \\
\hline 1. & Bambusa vulgaris Bvs Bvs-4 & 07 & $\mathrm{TC}$ & $\begin{array}{l}\text { TERI(seedling from less } \\
\text { thorny mother from } \\
\text { south \& TC }\end{array}$ & 4 \\
\hline 2. & Bambusa bambose Bbs-4 & 00 & $\mathrm{TC}$ & $\begin{array}{l}\text { TERI(seedling from less } \\
\text { thorny mother from } \\
\text { south \& TC }\end{array}$ & 3 \\
\hline 3. & Dendrocalmus asper Das-3 & 11 & $\mathrm{TC}$ & $\begin{array}{l}\text { Century laminates Pvt } \\
\text { ltd Hapur }\end{array}$ & 3 \\
\hline 4. & Bambusa nutans Bnts-1 & 03 & Offset & FRI DehraDun & 5 \\
\hline 5. & $\begin{array}{l}\text { Dendracalamus strictus } \\
\text { Dstc Dstc-5 }\end{array}$ & 16 & Seedling & Kotdwar (UK) & 5 \\
\hline 6. & $\begin{array}{l}\text { Dendracalmus hamiltonii } \\
\text { Dhn-1 }\end{array}$ & 13 & Offset & Molichak, Palampur & 3 \\
\hline 7. & $\begin{array}{l}\text { Dendracalmus } \\
\text { membranaceous Dms-1 }\end{array}$ & 15 & Offset & FRI DehraDun & 3 \\
\hline 8. & $\begin{array}{l}\text { Thyrsostaehyus oliberi Tolv- } \\
2\end{array}$ & 24 & Offset & Tripura, Katlamara & 3 \\
\hline 9. & Bambusa balccooa Bbo-1 & 01 & Offset & $\begin{array}{l}\text { Kalinagar (origin from } \\
\text { south of } 24 \text { Parganas, } \\
\text { WB }\end{array}$ & 4 \\
\hline
\end{tabular}

Table.1b Performance of various clones (Species) after one year of growth on number of shoots developed (per clumps) and girth $(\mathrm{cm})$ under Eastern U.P. condition

\begin{tabular}{|c|l|c|c|}
\hline SI. No & \multicolumn{1}{|c|}{$\begin{array}{c}\text { Clone (Germplasm) } \\
\text { Species }\end{array}$} & $\begin{array}{c}\text { Number of shoot } \\
\text { developed }\end{array}$ & Girth $(\mathbf{c m})$ \\
\hline $\mathbf{1}$ & Bambusa vulgaris & 10 & 3.37 \\
\hline $\mathbf{2}$ & Bambusa bambos & 6 & 4.08 \\
\hline $\mathbf{3}$ & Dendrocalmus asper & No sprout & No sprout \\
\hline $\mathbf{4}$ & Bambusa nutans & 15 & 1.88 \\
\hline $\mathbf{5}$ & Dendracalamus strictus & 14 & 2.10 \\
\hline $\mathbf{6}$ & Dendracalmus hamiltonii & 6 & 5.09 \\
\hline $\mathbf{7}$ & Dendrocalmus asper & No sprout & No sprout \\
\hline $\mathbf{8}$ & Thyrsostachyus oliveri & No sprout & No sprout \\
\hline $\mathbf{9}$ & Bambusa balcooa & 16 & 1.60 \\
\hline & S.Em. \pm & 0.99 & 0.05 \\
\hline & CD at 5\% of level & 2.98 & 0.15 \\
\hline
\end{tabular}


Table.2 Performance of various species after $2^{\text {nd }}$ and $3^{\text {rd }}$ years of growth in the Clonal Garden of NDUAT, Faizabad: Number of shoots developed per clump

\begin{tabular}{|r|l|c|c|}
\hline \multirow{2}{*}{$\begin{array}{l}\text { Sl. } \\
\text { No }\end{array}$} & Species & \multicolumn{2}{|c|}{ Number of shoots developed/clump } \\
\cline { 3 - 4 } & & $2^{\text {nd }}$ Year of growth & $3^{\text {rd }}$ year of growth \\
\hline $\mathbf{1}$ & Bambusa vulgaris & 15 & 21 \\
\hline $\mathbf{2}$ & Bambusa bambos & 10 & 16 \\
\hline $\mathbf{3}$ & Bambusa balcooa & 20 & 26 \\
\hline $\mathbf{4}$ & Bambusa nutans & 19 & 27 \\
\hline $\mathbf{5}$ & Dendracalamus strictus & 19 & 28 \\
\hline $\mathbf{6}$ & Dendracalmus hamiltonii & 11 & 16 \\
\hline & S.Em \pm & 1.05 & 1.01 \\
\hline & CD at 5\% of level & 3.16 & 3.02 \\
\hline
\end{tabular}

Table.3 Performance of various Species at $2^{\text {nd }}$ and $3^{\text {rd }}$ years of growth in the Clonal Garden of NDUAT, Faizabad: Girth at $5^{\text {th }}$ internodes

\begin{tabular}{|c|l|c|c|}
\hline Sl. No & Clone (Species) & \multicolumn{2}{|c|}{ Girth (cm) } \\
\cline { 3 - 4 } & & $2^{\text {nd }}$ year of growth & $3^{\text {rd }}$ year of growth \\
\hline $\mathbf{1}$ & Bambusa vulgaris & 6.00 & 8.00 \\
\hline $\mathbf{2}$ & Bambusa bambos & 7.00 & 9.99 \\
\hline $\mathbf{3}$ & Bambusa balcooa & 4.20 & 8.20 \\
\hline $\mathbf{4}$ & Bambusa nutans & 3.00 & 5.38 \\
\hline $\mathbf{5}$ & Dendracalamus strictus & 5.00 & 9.00 \\
\hline $\mathbf{6}$ & Dendracalmus hamiltonii & 9.20 & 14.20 \\
\hline & S.Em \pm & 0.45 & 0.33 \\
\hline & CD at 5\% of level & 1.35 & 0.99 \\
\hline
\end{tabular}

Like wise Number of shoots obseved maximum (20) in Bambusa balcooa in second year and (28) in Dendracalamus strictus in third year of planting. Maximum girth were observed $(9.20 \mathrm{~cm})$ and $(14.20 \mathrm{~cm})$ in Dendracalmus hamiltonii in second and third year of planting. These findings could be due genetical as well as due to the environmental effect.

\section{References}

Bystriakova, N., Kapos, V., Stapleton, C., and Lysenko, I. (2003). Bamboo Biodiversity: Information for Planning Conservation and Management in the
Asia-Pacific Region. Beijing: UNEPWCMC/INBAR

Capuli F.A. (1992). Mass Propagation of Bamboo Proceeding of the Regional Symposium AS/91/004, Field Document No.4. Regional Symposium RAS/91/004, Field Document No.4.

Gomez, K.K. and Gomez, A.A. (1984). Statistical procedure for Agriculture Research, A Wiley Int. Pub., John Wiley and Sons, New York, pp. 680.

Kleinhenz, V. and Midmore, D.J. (2001). Aspects of Bamboo Agronomy. Advances in Agronomy, 74, 99-153.

Nagariya, M.N. and Sunil Puri (1997). Bamboo: production and uses. Indira 
Gandhi agricultural university, Raipur (C.G.) Sharma, B.D., D.K. Hore, G. Pandey and B.M. Wadhwa (1992). Genetic resources of bamboo in the NorthEastern region of India. Ind. J. For. 15:
44-51

Singhal, R.M. and P.B. Gangopadhyay (1999). Bamboo in India. ICFRE, Dehradun.

\section{How to cite this article:}

Ashok Kumar and Abhinav Kumar. 2018. Assessment of Bamboo Species Under Eastern U.P. Conditions. Int.J.Curr.Microbiol.App.Sci. 7(11): 3230-3235.

doi: https://doi.org/10.20546/ijcmas.2018.711.371 